\title{
Виталик в наших сердцах
}

\author{
В.А. Мордвинов凶
}

Для цитирования: Мордвинов В.А. Виталик в наших сердцах. Письма в Вавиловский журнал генетики и селекции. 2020;6(4):201-204. DOI 10.18699/Letters2020-6-27

\section{Vitalik in our hearts}

\author{
V.A. Mordvinov $\bowtie$
}

For citation: Mordvinov V.A. Vitalik in our hearts. Pisma v Vavilovskii Zhurnal Genetiki i Selektsii = Letters to Vavilov Journal of Genetics and Breeding. 2020;6(4):201-204. DOI 10.18699/Letters2020-6-27 (in Russian)

Виталий Лихошвай есть и будет весьма заметной фигурой в отечественной математической биологии. Он много сделал для развития и укрепления школы математического моделирования в ИЦиГ СО РАН. В Институте продолжают работать его друзья, ученики и коллеги, продолжают выходить его статьи. Нет сомнения, что многие темы, предложенные Виталием, будут успешно развиваться.

Виталий был высокоэрудированным человеком. Профессиональный математик, он глубоко знал общую и молекулярную биологию, хорошо разбирался в биохимии, с ним всегда было интересно обсуждать проблемы биомедицины. Я уверен, что Виталий мог эффективно реализовать себя не только в математической биологии, но и во многих других науках.

Он родился ученым. Способность схватывать суть явлений и отделять главное от второстепенного, трудолюбие, интуиция и воображение - всем этим Виталий был наделен в полной мере. Легко принимал нестандартные решения, в его идеях всегда была научная смелость, всегда чувствовалось стремление к гармонии. Так почему же его специальностью стала именно математическая биология? Скорее всего, как и у многих, это тесно связано с цепочкой событий, происходивших с ним в юные и зрелые годы. Я хочу рассказать о некоторых эпизодах из жизни Виталия, которые, с моей точки зрения, серьезно повлияли на его научную судьбу.
Ближайшие родственники Виталия - жена, Ирина Орловская ${ }^{1}$ и дочери, Ирина ${ }^{2}$ и Татьяна ${ }^{3}$, с большой благодарностью отнеслись к идее посвятить Виталию один из выпусков «Писем в Вавиловский журнал генетики и селекции». Они приняли участие в подготовке этой рукописи, и я считаю их своими соавторами.

Виталий Лихошвай родился в Украине, в селе Терешки Полтавской области. В 1954 году его родители, Александр Ананьевич и Александра Емельяновна, вместе с шестимесячным Виталием уехали в Сибирь по комсомольской путевке. Их направили на стрелочный завод Первомайского района Новосибирска и дали жилье неподалеку. Через 5 лет у Виталия появился брат - Валера.

Отец Виталия умер рано, мама продолжала работать на заводе; семья была похожа на многие другие рабочие семьи. Мальчики учились в школе, расположенной рядом с их домом. Школа была самая обыкновенная, Виталий учился хорошо, но в начале учебы, как и большинство сверстников,

\footnotetext{
1 Ирина Анатольевна Орловская, доктор медицинских наук, профессор, заведующая лабораторией иммунобиологии стволовой клетки Научноисследовательского института фундаментальной и клинической иммунологии СО РАН

2 Ирина Витальевна Шевченко, начальник отдела единой регистратуры ФГБУ «НМИЦ им. акад. Е.Н. Мешалкина» Минздрава России

3 Татьяна Витальевна Калымбетова, Dr. biol. hom., младший научный сотрудник лаборатории ПЦР АО «Вектор-Бест»
} 
особой тяги к какому-либо предмету не проявлял. Не исключено, что он мог последовать примеру родителей и после окончания учебы пойти работать на завод, что и сделал его брат. Но произошло, в общем-то, неприятное событие, во многом счастливо определившее его дальнейшую жизнь.

В четвертом классе Виталий заболел, и для полного выздоровления ему пришлось на несколько месяцев отправиться в детский санаторий. Здесь тоже была школа, и дети продолжали учиться по стандартной программе. Виталий рассказывал, что в школе было много хороших преподавателей, но особенно он выделял учительницу математики. Именно она разбудила в нем интерес к этому предмету, и рассказы «как я стал математиком» Виталий всегда начинал со встречи с этой учительницей. Он очень ее ценил, поддерживал с ней связь долгие годы. К сожалению, я не запомнил имени любимой учительницы Виталия и не сумел найти знакомых, ее знавших.

После школы Виталий поступил на механико-математический факультет Новосибирского государственного университета. Он увлекся алгеброй и решил выполнить дипломную работу в отделе математической логики Института математики СО АН СССР. Его руководителем был лидер сибирской школы алгебры и логики, академик Юрий Леонидович Ершов. В 1976 году Виталий успешно защитил диплом и, вероятно, мог поступить в аспирантуру Института математики. Но он принял решение заняться математической биологией.

Думаю, на первых порах решение Виталия базировалось, в основном, на житейских соображениях. Незадолго до его выпуска из университета в Академгородке был официально открыт новый институт - ВНИИ молекулярной биологии, нынешний «Вектор». Молодость института выражалась в том числе и в отсутствии собственного кадрового резерва дипломников и аспирантов. Служба ученого секретаря и отдел кадров ВНИИ МБ вели активный поиск потенциальных сотрудников среди выпускников НГУ. Высокая конкурентоспособность ВНИИ МБ в борьбе за талантливую молодежь с другими институтами Новосибирского научного центра достигалась обещаниями современных квартир и высоких зарплат. Кроме того, было известно, что молодые ученые ВНИИ МБ будут иметь возможность пройти годичную стажировку в лучших московских НИИ. Одним словом, новый институт был очень привлекательным местом работы, и его администрация имела возможность выбрать себе достойные научные кадры. По своей квалификации Виталий подходил для работы в только формирующемся отделе математического моделирования. Его пригласили на собеседование, а затем взяли в штат.

Начало работы Виталия в отделе математического моделирования ВНИИ МБ практически совпало с его знакомством с Сергеем Ивановичем Бажаном ${ }^{4}$. Эта встреча, на мой взгляд, стала одним из важнейших событий в жизни Виталия и имела множество позитивных последствий.

С.И. Бажан руководил лабораторией, в которую направили Виталия. Я уверен, именно он сумел так ввести Виталия

\footnotetext{
4 Сергей Иванович Бажан, доктор биологических наук, профессор, заведующий теоретическим отделом Государственного научного центра вирусологии и биотехнологии «Вектор»
}

в математическую биологию, что эта наука стала для него главной. Сергей Иванович был научным руководителем кандидатской диссертации Виталия и остался для него навсегда одним из самых авторитетных ученых. Они были разными, но удивительно гармонично дополняли и усиливали друг друга. Спокойствие и уравновешенность Сергея Ивановича замечательно сочетались с порывистостью Виталия. Их объединяло огромное трудолюбие и любовь к научной работе. Определенно, они учились друг у друга, сами того не замечая. Биолог Бажан, прошедший школу ИЦиГ, и математик Лихошвай стали ведущими специалистами ВНИИ МБ в области математического моделирования биологических процессов. Инициированные ими работы по теоретическому анализу закономерностей функционирования живых систем во многом были пионерскими исследованиями. Так, математическая модель онтогенеза бактериофага лямбда, над которой Виталий продолжал работать долгое время и которая в контексте его исследований может считаться классикой, была выполнена во ВНИИ МБ в лаборатории С.И. Бажана.

Совместная работа переросла в крепкую мужскую дружбу, и Сергей Иванович оставался для Виталия очень близким человеком всю жизнь. Их дружба стала семейной, а позже перешла к молодому поколению Бажанов и Лихошваев. Такое нечастое явление очень украшает жизнь двух семейств.

В начале девяностых на ВНИИ МБ, как и на большинство исследовательских институтов, навалилось множество проблем. Финансирование науки резко сократилось, истощались резервы институтов по оборудованию, комплектующим и реактивам, зарплаты сотрудников на фоне невероятной инфляции становились мизерными. Для российских ученых это был период безденежья, массового отъезда за рубеж или перехода на другую работу. Жена Виталия работала в НИИ клинической иммунологии, страдавшем от недостатка финансирования не менее, чем ВНИИ МБ; в семье росли две маленькие девочки. Виталий не хотел уходить из института, но необходимость в буквальном смысле кормить семью вынудила его искать вторую работу.

Его пригласили в частную компанию, ориентированную на поставку товаров в Новосибирск из ближнего зарубежья. Дела в новой сфере деятельности складывались неплохо, дополнительная работа позволяла семье справляться с суровыми временами. Думаю, у Виталия была возможность закрепиться в этой или в какой-нибудь другой успешной коммерческой компании, а со временем стать и самостоятельным бизнесменом. Однако, я уверен, он никогда не собирался менять профессию и рассматривал коммерцию как временную необходимость.

Вторая работа отнимала много времени от занятий наукой. Тем не менее Виталий продолжал балансировать между занятием для души и деятельностью в коммерческой компании. Не думаю, что в таком положении можно чувствовать себя комфортно. В семье уже были как-то решены финансовые вопросы, можно было подумать о завершении работы в коммерции. Но это непростое решение, здесь часто бывает нужен дополнительный толчок, волна позитива, на которой оптимальное решение приходит само собой. Го- 


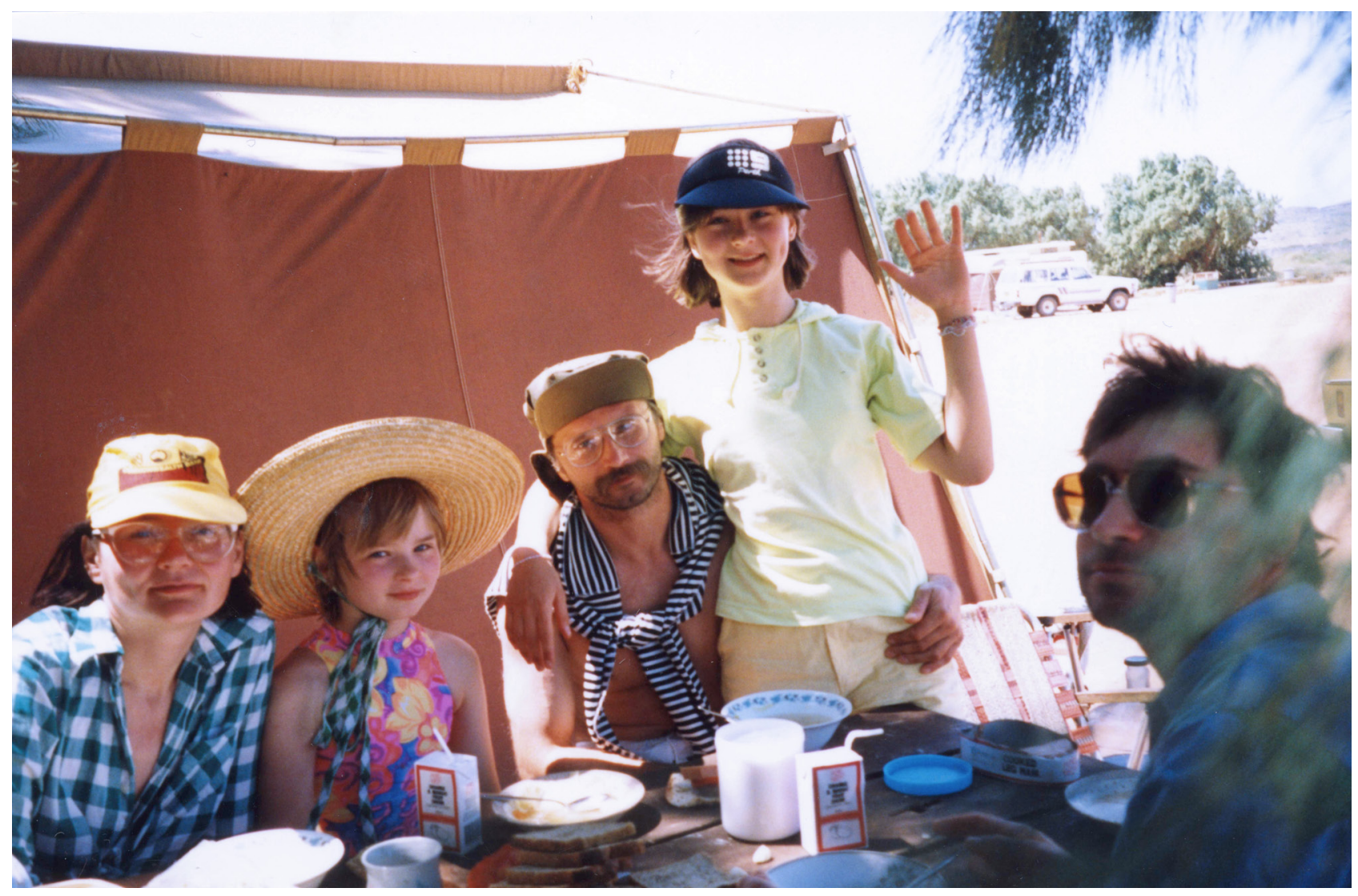

Виталий Александрович Лихошвай с семьей во время путешествия по Австралии, 1996

ворят, нужно «поменять картинку за окном», освободиться от ежедневной рутины, забыть на время рабочие проблемы и окунуться в другую жизнь. Нужен был хороший отпуск с путешествиями и приключениями, после которого взгляд на жизнь наполняется оптимизмом и появляется энергия, не дающая этому оптимизму исчезнуть. К счастью, таким отпуском оказалась поездка всей семьи Виталия в Австралию, и об этом, в общем-то непродолжительном, путешествии я хочу рассказать подробнее.

Наши с Виталием жены - родные сестры, сохранившие нежную привязанность друг к другу до сего дня, и между нашими семьями всегда существовала тесная связь. В девяностые я работал в университете Западной Австралии, и мы с женой жили в замечательном городе Перт. Через пару лет мы уже неплохо там освоились и смогли организовать приглашение провести отпуск в Австралии для Виталика (так мы в семье его звали), Ирины и дочерей. В 1996 году семейство Лихошваев, справившись со всеми формальностями, необходимыми для такой поездки, прибыло в Перт.

Атмосфера большого совместного отпуска была легкой и праздничной. Австралийские друзья и мои коллеги по работе знали о приезде наших родственников. Многим было любопытно пообщаться с большим семейством сибиряков, и нас часто приглашали в гости, на пикники или поездки по окрестностям Перта. Мы с удовольствием принимали приглашения, радовались гостеприимству друзей и тоже часто приглашали гостей.
Среди наших друзей и знакомых были биологи, врачи, геологи, строители, но математиков - не было. Это создавало Виталику некий ореол необычности и часто служило поводом для общения. Внимание австралийцев было ненавязчивым и, мне кажется, нравилось ему. Он подружился с Фридом, хозяином дома, в котором мы жили. Между прочим, Виталик помог ему сделать расчеты для строительства беседки и убедительнейшим образом проиллюстрировал их с помощью небольшой модели. Фрид построил беседку и потом всегда рассказывал, что идея этой легкой и изящной конструкции принадлежит русскому математику Виталию.

Значительную часть отпуска мы посвятили большому путешествию по Австралии, и во время этой поездки Виталик волею случая стал настоящей знаменитостью. Мы забрались довольно далеко на Север, где почти нет поселений, а заправочные станции разделяют большие расстояния. Там и порвалась шина у колеса прицепа, груженного вещами и припасами. Мы быстро поставили запаску, но буквально через 10 минут у прицепа лопнуло второе колесо, заменить которое было уже нечем. Перегрузить вещи в машину было нельзя: нас шесть человек, и багажник загружен под завязку. Оставить посреди пустыни прицеп с вещами было боязно. Виталик вызвался остаться и сторожить наше добро, пока я, с женами и детьми, смотаюсь за новым колесом. Мы спустили прицеп с дороги и оставили отца семейства в прериях, снабдив его большой соломенной шляпой для защиты от солнца. 
До ближайшей заправки было 70 км, там я надеялся купить колесо и через полтора часа вернуться. Но подходящего колеса у них не оказалось. Мобильных телефонов у нас тогда еще не было, и позвонить Виталику мы не могли. Пришлось дождаться машины, направлявшейся в его сторону: с ней мы отправили записку с предупреждением, что задерживаемся. Не было нужного колеса и на следующей заправке. Я пошел искать машину, чтобы передать Виталику вторую записку, и неожиданно услышал разговор. Обсуждали человека, разбившего лагерь на пустынном участке трассы рядом с дорогой: «Этот симпатичный парень вежливо отвечает на приветствия проезжающих, от предложений чем-нибудь помочь отказывается и говорит, что у него все в порядке».

...Поиски колеса затянулись; мы вернулись к Виталику только через шесть часов. За это время слух о нем распространился по ближним и дальним заправочным станциям.
Мои рассказы про лопнувшие колеса были забыты или перевраны, и многие готовы были сделать крюк километров эдак в 30-70, чтобы взглянуть на любителя пустыни, путешествующего на прицепе: будет о чем рассказать друзьям!

Надо отметить, что Виталику это маленькое приключение понравилось и он потом с удовольствием рассказывал о нем как об изюминке нашего путешествия по Северу Австралии, а может и австралийских каникул в целом.

Вскоре по приезде в Новосибирск Виталий поступил на работу в ИЦиГ и полностью погрузился в науку. Я думаю, путешествие было той самой волной позитива, которая помогла ему принять это важное решение и окончательно расставить жизненные приоритеты. Нельзя, конечно, помещать в один ряд австралийский отпуск и встречу Виталика с первой учительницей математики или дружбу с Сергеем Ивановичем Бажаном. Просто я очень рад, что это было в нашей общей с ним жизни.

Конфликт интересов. Автор заявляет об отсутствии конфликта интересов.

Поступила в редакцию 11.09.2020. После рецензирования 04.10.2020. Принята к публикации 06.10.2020. 